grond hiervan heeft de commissie geoordeeld dat de arbeidsovereenkomst niet met onmiddellijke ingang per 1, respectievelijk 3 mei 2020 rechtsgeldig is beëindigd.

In het kader van de gevorderde vergoedingen heeft de arbitragecommissie overwogen dat het handelen van Maletic ontoelaatbaar was, maar in het licht van de gegeven omstandigheden niet zodanig dat dit een ontslag op staande voet zou hebben gerechtvaardigd. De commissie heeft de vergoeding wegens het voortijdig verbreken van de arbeidsovereenkomst ex art. 7:677 lid $4 \mathrm{BW}$ derhalve toegewezen, maar wel gematigd tot een bedrag van EUR 16.000. De commissie heeft de billijke vergoeding, boven op de vergoeding wegens onregelmatige opzegging, afgewezen omdat Maletic zich niet heeft gedragen zoals van een goed werknemer verwacht had mogen worden en hij redelijk snel een nieuwe betaalde baan heeft gevonden na het ontslag bij PSV.

\section{VSZ 2021/6}

\section{Rb. Midden-Nederland 23 november 2020, \\ ECLI:NL:RBMNE:2020:5111 (VoetbalTV/AP)}

\section{VoetbalTV hoeft boete Autoriteit Persoons- gegevens van EUR 575.000 niet te betalen.}

VoetbalTV B.V. (VoetbalTV) was een in 2018 opgericht videoplatform voor het amateurvoetbal dat in opdracht van voetbalverenigingen video-opnamen makkte van amateurvoetbalwedstrijden van senioren en jeugdspelers ouder dan 13 jaar. VoetbalTV had meer dan 500.000 gebruikers. Op het platform van VoetbalTV konden gebruikers voetbalmomenten terugkijken, wedstrijden analyseren, gegevens verzamelen en delen met anderen. VoetbalTV bood ook een analysetool waar trainers/ analisten gebruik van kunnen maken. De Autoriteit Persoonsgegevens (AP) heeft bij besluit van 16 juli 2020 aan VoetbalTV een boete opgelegd ter hoogte van EUR 575.000 voor het onrechtmatig verwerken van persoonsgegevens omdat VoetbalTV zonder rechtmatige grondslag video-opnamen zou hebben gemaakt van een groot aantal amateurvoetbalwedstrijden en deze beelden verder zou hebben verspreid onder een groot publiek via haar platform. Dit zou in strijd zijn met de Algemene Verordening Gegevensbescherming (AVG). Door de handelwijze van VoetbalTV zijn volgens de AP de betrokkenen, waaronder veel minderjarigen, de controle over hun persoonsgegevens (voor een deel) kwijtgeraakt. VoetbalTV heeft beroep ingesteld tegen het besluit van AP bij de rechtbank. Hoewel VoetbalTV op 11 september 2020 failliet is verklaard, wordt het beroep door de rechtbank behandeld, omdat partijen reeds voor het faillissement voor een zitting waren uitgenodigd.

VoetbalTV voert bij de rechtbank aan dat zij persoonsgegevens mocht verwerken op grond van de journalistieke exceptie, alsmede omdat zij voor verwerking een gerechtvaardigd belang had en daarmee een wettelijke grondslag. De AP betwist deze stellingen en stelt dat het te gelde maken van persoonsgegevens nooit een gerechtvaardigd belang kan opleveren. De rechtbank oordeelt dat van de journalistieke exceptie geen sprake is, omdat het opnemen van de voetbalwedstrijden en het uitzenden daarvan aan het publiek in dit geval niet uitsluitend een journalistiek doel dient. De rechtbank volgt de AP echter niet in haar standpunt dat VoetbalTV geen gerechtvaardigd belang kan hebben omdat VoetbalTV een commercieel belang heeft. Het op voorhand uitsluiten van een bepaald belang als gerechtvaardigd belang, is in strijd met de Europese rechtspraak. De AP had het gerechtvaardigd belang op een meer open en flexibele manier dienen uit te leggen dan vast te houden aan een strikte toepassing. De AP heeft daarmee miskend dat het begrip 'gerechtvaardigd' belang vooral als buitengrens dient voor de beoordeling en niet als een drempel. De AP moet juist een onderzoek doen naar de belangen van VoetbalTV en vervolgens een afweging maken of zij door het uitzenden van de amateurvoetbalwedstrijden de privacy van betrokkenen ontoelaatbaar schendt. De manier waarop verweerder deze toetsing moet uitvoeren volgt uit de rechtspraak van het Hof van Justitie. Het beroep van VoetbalTV is dan ook gegrond en de rechtbank vernietigt het besluit van de AP waarin de boete was opgelegd. De rechtbank voorziet met toepassing van art. 8:72a Awb zelf in de zaak, in die zin dat zij geen ander besluit neemt in de plaats van het vernietigde besluit. Als gevolg daarvan is de boete geheel van tafel.

NB. Het gerechtvaardigd belang is vaak een grondslag voor verwerking van persoonsgegevens in de sport. Als deze uitspraak navolging krijgt, zullen sportorganisaties dan ook minder snel beperkt worden in de mogelijkheden om persoonsgegevens te verwerken. De AP legde reeds eerder een boete op van EUR 525.000 op aan de KNLTB voor de verkoop van ledengegevens aan sponsoren en legde daaraan ook ten grondslag dat een commercieel belang nimmer een gerechtvaardigd belang zou kunnen opleveren. ${ }^{3}$
3. Vgl. M. Jansen, KNLTB-boete: wie kaatst kan de bal verwachten of toch een misslag?, Computerrecht 2020/180. 